\title{
OPEN REGIONALISM, APEC AND CHINA'S INTERNATIONAL TRADE STRATEGIES
}

\section{PETER DRYSDALE}

While developments over the past few years have raised many questions about the immediate prospects for East Asia's economic growth, the force of East Asian industrialisation has already transformed the contours of world economic power and influence (Drysdale and Elek 1997). Japan was the leading edge of East Asian industrialisation and, in the postwar period, emerged to join the same league as the industrial economies of North America and Europe. The new role that East Asia began to assume more clearly in the 1980s was defined in a pluralist structure of economic power, encompassing the effective representation of broader Asia Pacific and global interests, as well as those of the United States and Europe (Funabashi 1995:Ch. 9).

Strong commitment to these regional and global goals has provided the stimulus for every major initiative for economic cooperation in the Asia Pacific region for more than thirty years, from the establishment of the Pacific Basin Economic Council (PBEC) and the Pacific Trade and Development (PAFTAD) Conference series, through to the foundation of the Pacific Economic Cooperation Council (PECC) and the APEC forums. In all of these initiatives Australia and Japan played a leading role, crucially engaging the ASEAN countries, winning the support of the United States in the PECC and later the APEC initiative (Drysdale 1988; Terada 1998) and later incorporating the interests of the Chinese economies (Drysdale 1997b). From 1999, China was also actively involved in dialogue with Australia on these issues.

The establishment of APEC was part of the response to the need for regional structures in the Asia Pacific, notable for their paucity compared with those in the Atlantic. Asia Pacific community-building was needed to cope with the realities of growing economic interdependence (APEC 1993), and to allow Asia Pacific governments to contribute to collective leadership to shape a new global order following the end of the Cold War (Funabashi 1995:Ch. 9; Drysdale 1991). 


\section{CENTRAL PRINCIPLES}

At the core of the APEC philosophy is the idea of 'open regionalism' (Funabashi 1995:3). From its beginnings, APEC 'was not to be an economic bloc or legally bound free trade area like the European Community or the North American Free Trade Agreement (NAFTA)'. Rather, APEC 'sought to realise a vision of global free trade, driven by the liberalisation of the Asia Pacific region's dynamic economies' (Funabashi 1995:3). The objective of promoting economic consultation and cooperation among Asia Pacific governments was essentially a conservative one, to preserve the conditions needed to sustain the positive trends of rising prosperity and the productive integration of the region's economies (Garnaut 1996:Ch. 1).

Hence, APEC was born in 1989 out of deep concern among Fast Asian and Western Pacific economies about the fate of the global, multilateral trade regime and the slow progress of multilateral trade negotiations in the Uruguay Round through the 1980s.

The East Asian economies understood their stake in the strength and continuity of an open trading system, based upon the principle of non-discrimination in trade embedded in Article 1 of the GATT. This was why the idea of open regionalism came to define the approach to the development of APEC and Asia Pacific integration from its beginnings.

The idea of open regionalism is deeply rooted in the history of the evolution of APEC. The experience of discriminatory trade policies of the interwar period is seared into Japanese policy memory, and non-discrimination in trade policy stands out as the central guiding principle of Japan's postwar international trade diplomacy. Takeo Miki, one of the early advocates of Asia Pacific economic cooperation, declared that 'it would be an act of suicide on our part to create an exclusive and closed trading bloc in the Pacific area' (Miki 1968). A little over a decade later, the Ohira Study Group concluded that 'a regionalism that is open to the world, not one that is exclusive and closed, is the first characteristic of our concept a regional community... without a perspective for a global community has no possibility of development and prosperity' (Japan Pacific Cooperation Study Group 1980:19). These ideas were first given precision in English at the Pacific Community Seminar convened by Crawford at the initiative of Prime Ministers Ohira of Japan and Fraser of Australia at The Australian National University in September 1980 (Garnaut 1996:6). They became entrenched through the work of PECC after 1980 and were the intellectual foundation on which APEC was launched in Canberra in November 1989 (Crawford and Seow 1981; Drysdale, Elek and Soesastro 1998).

\section{PRECEPTTO PRACTICE}

APEC's agenda has evolved around the giving of substance to the idea of open regionalism. The APEC meetings in Seattle in 1993 elevated the process of 
cooperation to the highest level of government. At the initiative of US President Clinton, an APEC informal leaders meeting was held in conjunction with the established ministerial meetings. The leaders issued an Economic Vision Statement which contained three elements. The first was an affirmation of an open multilateral trading system and the determination of Asia Pacific leaders to take steps to produce the strongest possible outcome of the Uruguay Round (APEC 1993). The APEC leaders meeting the following year in Bogor (Indonesia) produced the Bogor Declaration of Common Resolve (APEC 1994), which set the goals of free and open trade and investment in the region by 2010 for developed members and 2020 for developing member economies. The commitment by leaders to achieve free and open trade by a certain date was an important milestone in APEC's development.

In spite of the principles set out in the Bogor Declaration, there remained some ambiguities about the modality for achieving the APEC goal of free and open trade and investment in the region. These arose in proposals, including those put forward by the APEC Eminent Persons Group (APEC Eminent Persons Group 1994), which amounted to advocacy of a process of negotiated liberalisation among APEC members along the lines of a conventional free trade area, whose benefits could be extended to non-member only on a mutually reciprocated basis and in a way that would eliminate the problem of 'free riding', either within APEC itself or by non-members, notably Europe.

The task of clarifying these issues rested with Japan-the chair of APEC in 1995.

APEC formally espoused open regionalism at its Osaka meetings in 1995 and the Osaka Action Agenda (APEC 1995) was premised on the voluntary nature of the APEC process, an essential corollary to the idea of open regionalism. Commitment to unilateral liberalisation of barriers to trade and investment by APEC members, in their own self interest, is a necessary condition of progress on the basis of open regionalism. Such commitments are not seen as concessions for exchange in a negotiating process, but their collective effect (concerted unilateral liberalisation) is mutually reinforcing of regional trade liberalisation, consistently with Article 1 of the WTO and without requiring an Article 24 style discriminatory agreement (Drysdale, Elek and Soesastro 1998).

Equally important, in the context of Asia Pacific community-building, is the sense of comfort that this modality provides to APEC member economies, by allowing flexibility in the implementation of liberalisation commitments not based on uniformly negotiated schedules. APEC's trade liberalisation and facilitation agenda is adopted and implemented by the decisions of individual governments. Each member's liberalisation program is entered into voluntarily, in accordance with common guidelines for APEC cooperation adopted by consensus within the APEC process. Unilateral efforts are reviewed and monitored within APEC. As agreed in Osaka, members' Individual Action Plans (IAPs) cover trade 
liberalisation and trade and investment facilitation measures. In addition, Collective Action Plans (CAPs) open the possibility of non-discriminatory sectoral liberalisation, in sectors of special interest to APEC members, an option that was taken up in the Vancouver APEC meetings of November 1997. In Manila, APEC members also laid the basis for adoption of the Information Technology Agreement at the WTO Ministerial Meetings in Singapore in late 1996 and subsequently (APEC 1996).

In brief, there are three reasons why the East Asian and other Western Pacific economies have eschewed discrimination in the approach in the approach to Asia Pacific regional cooperation (Garnaut 1996). First, the trading interests of East Asian and Pacific economies extend beyond APEC, including to Europe. A conventional free trade area strategy towards liberalisation would deter internationally oriented reform in the region's neighbouring developing economies and introduce tension into relations with neighbours and major partners outside the region. Second, trade discrimination involves the unnecessary cost of trade diversion, complicated in the Asia Pacific region by the likelihood of high associated political costs both within and outside the region (Garnaut and Drysdale 1994:Ch. 5). Third, there is the sheer impracticability of undertaking regional trade liberalisation via a conventional discriminatory free trade area of the kind sanctioned by the WTO in such a diverse region-the most likely outcome would be a 'dirty bloc', in which there would be backsliding into partial preferential liberalisation, with a picking and choosing of the sectors to be liberalised, at different times, by different players, in bilateral deals (Drysdale, Vines and House 1998:7).

APEC has already become more than just a loose community of like-minded economies encouraging each other in a process of unilateral trade and investment liberalisation. It is also a structure, an umbrella, under which trade, technical cooperation, (recently) financial cooperation and, to a lesser extent, political tensions within the Asia Pacific region are managed.

\section{CHINA, WTO ACCESSION AND APEC}

\section{ACCESSION TO THE WTO}

The elevation of China's status in world trade has accelerated over the last several years, as the reform process has deepened and has encouraged active Chinese trade diplomacy in both global and regional fora.

Yet China itself is still outside the important global institutions that govern the rules and arrangements of the multilateral trading system. China has no access through membership of the WTO to representation or redress over matters of trade cooperation and application of the rules of trade it embodies, or over 
matters of trade disputation. China's political weight in international affairs and the power of mutual interests in bilateral economic arrangements provide it with influence in dealings with its international trading partners-even the United States, as was seen most clearly in 1994. But the fact remains that China has a much less confident basis on which to proceed in such dealings than other nations of comparable importance in world trade (Drysdale and Song 2000).

This is the crux of the priority that attaches to China's membership of the WTO and the importance of APEC in Chinese trade policy strategies.

China's entry to the WTO will affect Chinese and international policy and enterprise or corporate behaviour in at least three important respects. It will affect the behaviour of China's major trading partners, such as the United States, Europe and Japan, in policy behaviour towards China. It will affect Chinese policy behaviour, in respect of trade, investment and other rules and practices, and the environment in which both domestic and foreign firms operate in China. And it will affect the behaviour of domestic as well as foreign enterprises in their activities within the Chinese market. These consequences are of considerable importance even if, as will be the case from time to time, disputes or difficulties arise in the application of WTO rules and protocols by, and towards, China on whatever final terms entry is negotiated.

There are two key points here.

The first is that an international commitment, such as that involved in accession to the WTO, underwrites credibility in respect of the continuity and reliability of policy behaviour (Itoh 1996:8). It serves to limit opportunistic behaviour (such as quarantining favoured sectors of the economy from international competition, treatment of foreign firms on a different basis from national firms, treatment of a particular country's goods on a discriminatory basis or inconsistently with accepted rules and principles) and to reduce the likelihood of distortionary interventions in trade and other international transactions-both by China and by China's trading partners. Violation of WTO rules after entry would, of course, undermine policy credibility but, while many such problems do and may arise, the experience of China's approach to the honouring of its international agreements and of the approach of most WTO members to the trade rules suggest that China's entry to the WTO would secure an important international commitment and assurance of policy credibility both ways round. In this context, China's impressive trade liberalisation over the past decade cannot be viewed independently of negotiation towards GATT/WTO accession nor guaranteed independently of eventual success in these negotiations.

The second is that the international commitment required of China by WTO entry will bind policy and the evolution of policy in a way that affects the behaviour of domestic and foreign firms operating in China. Commitment to agreed rules and schedules of liberalisation changes the corporate strategic environment in 
which enterprises plan and develop their activities. While such policy change may not be entirely impervious to domestic pressuring and influence-peddling, it is likely to be less susceptible to easy resistance, manipulation and reversal than policy change undertaken without external constraint. The way in which Japan's accession to the GATT after the Second World War shaped corporate behaviour and the political economy in the 1950s and 1960s in that country is a relevant example of this effect (Itoh 1996:9-14).

\section{CHINA'S TRADE STRATEGY AND ECONOMIC REFORM}

A commitment to WTO rules and to meeting the standards of trade policy behaviour already achieved by the major players within the WTO-inadequate though these standards sometimes appear-implies a further radical change in China's economic policy regime, the necessary next step in meeting the objectives of economic reform. Accession to the WTO, and meeting the critical international obligations it must entail, can vastly assist the management of the reform process in China. The gains from the significant liberalisation of trade that China will phase in - through more efficient allocation of resources and its impact on the productivity of resource use-will be large, but there will also be costs in the process of adjustment, and the political resistance to these adjustments is not trivial. The resistance to change has origins in ideology and in appeal to other East Asian policy models, as well as in the vested interests in the highly protected and inefficient state enterprise sector and in the inefficient rural sector (Lu 1994; Hai 1996). Connecting the next important round of liberalisation in the Chinese economy to the benefits of more reliable access to the international marketplace, delivered through WTO accession, assists with managing the politics of reform. The successful conclusion of the Uruguay Round in 1994 considerably enhanced the economic and political benefit of the accession bargain for China, since faithful implementation of the Round will result in substantial liberalisation of the Multifibre Arrangement (MFA) governing textiles trade, an area of key interest in Chinese trade growth.

China's ambition to enter the WTO is a central element in the world trade policy agenda at the beginning of the twenty first century. This element needs to be reviewed in the broader context of the relationship between trade strategy and economic reform.

China's trade and economic policies are already considerably more in line with WTO principles than when it first applied for membership in July 1986. China undertook substantial economic reform in the 1980 s and the process of reform accelerated after 1989. Careful studies of the relationship between China's changing resource endowments and the structure of specialisation in the international economy provide strong evidence of the convergence between these patterns and what would be expected from market-determined outcomes 
(Song 1993). The marketisation of the Chinese economy - even of its state enterprise sector-is confirmed in studies of the behaviour of Chinese enterprises in the course of reform. While the state enterprise sector enjoys considerable direct and indirect support and there remains an array of measures that are inconsistent with the letter as well as the spirit of the WTO, including direct controls and subsidies, the stage has been set for state enterprise reform in a definable period of time so as to meet the objectives and requirements for WTO membership. The draft protocol of accession of December 1994 addressed this issue. The trade law of May 1994 laid an appropriate basis for ensuring the necessary transparency and uniformity in trade policy and a retreat from administrative in favour of market measures in the management of trade. The tariff liberalisation announced at the APEC meetings in Osaka in November 1995 and carried forward in the APEC meetings at Manila in November 1996 represented not only a considerable step towards achievement of China's trade liberalisation commitments under the APEC Bogor Declaration but also a substantial forward commitment on meeting the terms of accession to the WTO. The service sector (including banking and transportation) remains sheltered, but this sector as well as trade in commodities and technology is being thrown open to market principles.

In 1988 China's unweighted average tariffs were 40.3 per cent (PECC 1996:8). In 1993 they had been reduced to 37.5 per cent and by 1996 they were down to 23.0 per cent. The tariff average is now 15 per cent. China has substantially and steadily reduced the number of goods subject to quotas and licensing: at present around 700 tariff line items remain subject to nontariff trade barriers (NTBs), 600 of which are scheduled for removal. Figure 2.1 describes the extensive tariff reduction to which China is committed on a voluntary basis under the APEC Individual Action Plans (IAPs), significantly ahead of the trend necessary to achieve free trade in 2020 . China is also gradually opening up more sectors to direct foreign investment and progressively granting national treatment in foreign investment policy.

In practice, trade policy strategy is inextricably linked with other aspects of the reform, such as foreign exchange reform (already taken a long way through unification of the two-tiered exchange rate and with the target of full currency convertibility), state enterprise reform, financial market reform and macroeconomic policy reform.

The liberalisation of trade policy associated with accession to the WTO in effect forces the pace of reform in other areas, especially in the management of the state enterprise sector, and financial and foreign-exchange markets. Policy leaders, both inside and outside China, have a very substantial interest in forcing the pace. Accession to the WTO would entrench these reforms and help to maintain their momentum. 
The alternative would be a loss of momentum and serious misdirection of the process of reform and industrial transformation. One aspect is the potential for a shift towards costly 'import substitution' strategies fostered by the maintenance and extension of subsidies and state controls, and away from the thrust towards 'export orientation' or, more accurately, 'open market' strategies. Advancing the trade liberalisation agenda, through accession to the WTO, or by whatever means, promotes reform of the enterprise system through the positive effect of the export sector and enhanced market discipline on industrial activity.

In agriculture, the stakes are now set to become higher. China has switched from being an agriculture-taxing to an agriculture-subsidising industrialising economy (Drysdale 1997b). The burden of agricultural protection will become higher and higher and more difficult to unravel, unless the moment to negotiate a relatively open trade regime is taken soon.

Protectionist sentiment abroad and reactionary sentiment in China find common cause in focusing on strategies which eschew 'export-oriented' development and focus on 'self-sustaining' growth in a huge domestic market. Such thinking is based on incorrect understanding of the nature of industrialisation in East Asian economies. Chinese economic modernisation is not an independent event. In all the major East Asian economies, domestic market growth as well as openness to international market disciplines have been key elements in the development of dynamic comparative advantage and internationally competitive economies. The evolution of dynamic comparative advantage will differ in China from other East Asian economies because of the wider range in China's economic

Figure 2.1 China's tariff reductions

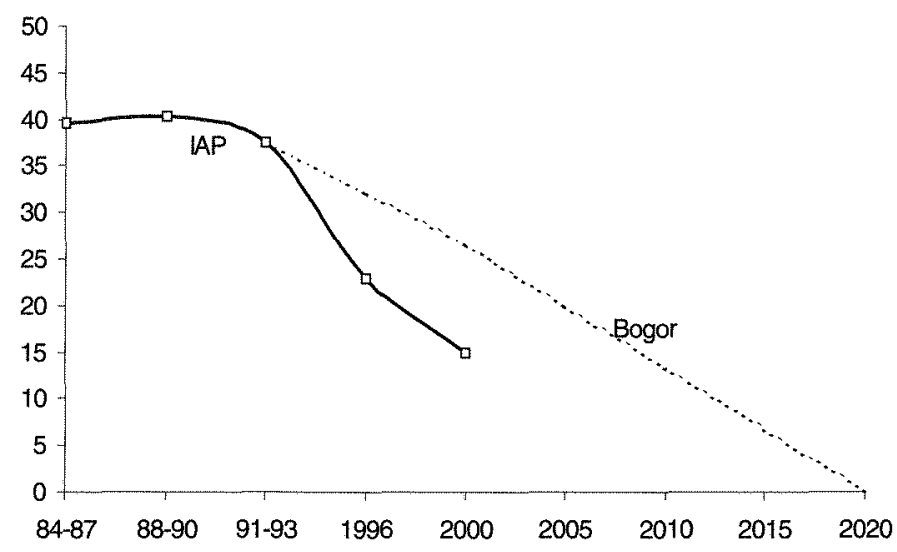

Source: PECC, 1996. Perspectives on the Manila Action Plan for APEC, Philippine Institute for Development Studies, Manila:13. 
structure, the regional diversity of its resource endowments and a history of investment in capital-intensive industry. But China is far from reaching its full potential in the development of externally oriented activities and will continue to realise significant gains from growth through trade, investment and technology flows and integration into the international economy.

This perspective is critical in judgment about the appropriate strategies towards industrial transformation and industrial policy in China.

\section{CHINA AND APEC}

China's trade and other foreign economic relations are overwhelmingly concentrated in the Asia Pacific economy (Table 2.1).

The APEC group of economies includes all China's most important trading partners and accounts for over 54 per cent of its import and export trade if Hong Kong's trade is included while that of China and trade between the two economies is excluded from their total trade. Among them are the United States and Japan. While the relationship with the United States is not free of problems (the human rights issue, arms sales, intellectual property rights, illegal textile trans-shipments, the Taiwan issue, and market access for US products in China) and the relationship with Japan carries the burden of history, China shares more interests with the Asia Pacific economies than with other trading nations. Trade ties have grown strongly within the region-even around diplomatic barriers to trade, such as those affecting trade with Taiwan or, until recently, with Korea. The growing depth of trade and business ties between China and the United States has begun to constrain the more divisive elements in bilateral relations and to encourage a strategy of engagement over any inclinations towards confrontation. APEC economies enjoy directly and disproportionately the benefits of China's economic growth and are natural allies in international economic diplomacy (Garnaut and Drysdale 1994:Ch.1).

The pioneering efforts by the PECC, tensions in trans-Pacific trade relations, the slow progress of the Uruguay Round and the European movement towards a single market all contributed to the launching of the APEC process in 1989 (Elek 1995). The PRC, Taiwan and Hong Kong were invited to join the process at the second ministerial-level meeting in Singapore in 1990, and all three participated in the third meeting in Seoul in November 1991. The inauguration of the informal leaders' meeting in Seattle in November 1993 gave APEC new clout and direction in a way that was of special importance to China.

The APEC framework provides a useful vehicle for Chinese foreign economic diplomacy in four main ways.

First, APEC provides a valuable forum within which the three Chinese economies can find common cause in regional economic cooperation. Second, APEC's objectives and principles, which stress the desirability of liberalisation 
APEC AND LIBERALISATION OF THE CHINESE ECONOMY

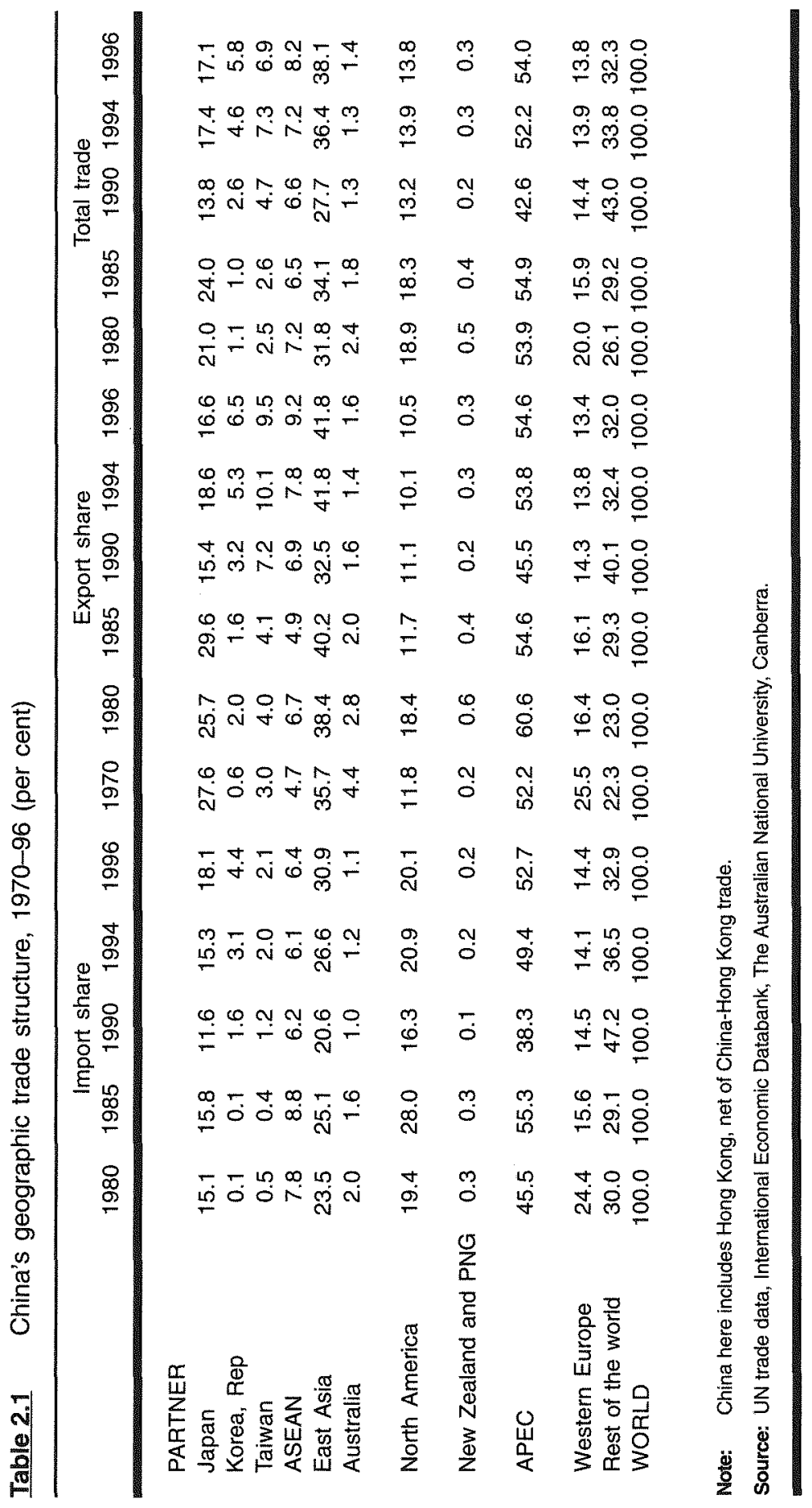


in ways that are not to the detriment of other economies, reinforce China's claim to MFN treatment in the international trading system, especially by its APEC partners. Third, APEC's focus on the facilitation of trade and other international transactions, and the regional infrastructure to support it, provides encouragement to sub-regional integration on a basis consistent with the guiding principle of open regionalism. The avoidance of sheltered, discriminatory, subregional markets is important to China's ability to manage its integration within the Northeast Asian economies (notably Hong Kong, Taiwan, and Korea) and develop its relations with the ASEAN and Indochinese economies. Asymmetry in China's relations with its neighbours has the potential to bedevil them unless they are part of an open trade and economic system in the region. This aspect of China's sub-regional relationships is also relevant to its response to Malaysia's East Asian Economic Caucus (EAEC) idea. China's involvement in any tight arrangement linked to the East Asian economies (even including Japan) is likely to be fraught with economic and political difficulty because of both the perception and the reality of asymmetry in such sub-regional arrangements. China is already a big economy and a big power and will have more comfortable relationships with smaller economies and polities, the more open those relationships are. Hence finally and most importantly, APEC is of particular value to China in the pursuit and projection of interests in the global system. The APEC framework offers the opportunity for a constructive and cooperative partnership between China and its major partners in the Asia Pacific region - the United States and Japanand a role in fostering peace, stability and prosperity on the world stage in ways helpful to China's own ambitions for reform and development.

China has indeed played a very positive role in developing the APEC agenda of trade and investment liberalisation, especially over the past five years, and in forging the link between its regional interests and the global agenda, consolidating the base for accession to the WTO through its initiatives at the Osaka and Manila APEC meetings. APEC, in turn, has been a critical vehicle through which China could re-position and maintain the momentum of its claim to WTO membership.

\section{CONFLICTING PARADIGMSACROSS THE PACIFIC}

APEC has special potential to be helpful in trans-Pacific relations. The tendency of the United States to conduct aspects of its trade relations bilaterally, and to seek bilateral reciprocity in its trade negotiations, is well known. It is also understandable. For a hegemonic power-which the United States still is-there is a natural temptation to use muscle to force market opening (in the name of both self interest and the general good). APEC has been a useful forum in which tensions between the United States and Japan, resulting from such actions by the United States, can be diffused and calmed. The APEC Summit in Manila 
also provided a congenial setting for Presidential talks to set United StatesChina relations on a more productive course. APEC has established its worth in managing trans-Pacific tensions through its serving as a vehicle for China's liberalisation agenda and its support for China's entry into the WTO. It was also effectively directed to management of the regional financial crisis in Vancouver, at the same time keeping the trade liberalisation agenda on track.

Yet there are aspects of developments in United States trade diplomacy over the last decade and a half that are potentially less benign for the prospects of open regionalism in APEC. These developments were born of impatience with the process of multilateral negotiation, frustration in large bilateral relationships such as those with Japan and Europe, and the challenge of the Single Market initiative in the European Union.

These developments, and the impact of the East Asian crisis, have recently aroused Japanese interest in sub-regional discriminatory trade arrangements.

Whether or not the awakening of United States interest in preferential trade arrangements was (or Japanese interest is) largely tactical, regionalism took on a life of its own among US policy makers (Saxonhouse 1997:2) and it remains an active interest, for example in consideration of new 'fast track' negotiating authority for the US Administration (Bergsten 1997).

This is the US policy context in which APEC was launched. It is also the policy context, it is worth remembering, in which Prime Minister Mahathir first put forward the idea of an East Asian Economic Caucus as, among other things, a tactical defence against North American regionalism. Of more relevance here, it is also the policy context in which a number of Americans, both inside and outside government have been eager to maintain a preferential trading arrangement option for APEC (Saxonhouse 1997:4).

Bergsten (1997:12) suggests a modification of open regionalism which qualifies its essential (most-favoured nation) feature. In his scheme, APEC members would afford liberalisation only to those outsiders who offered similar liberalisation themselves. The requirement for reciprocal liberalisation has earned this approach the label 'reciprocitarianism'. The element of conditionality in Bergsten's formula means that the final choice of whether free trade or a free trade area was the endpoint of reform would be left until tariff reduction reached its final stages. Flamm and Lincoln (1997) echo Bergsten's critique of open regionalism, strictly defined, in a recent tract.

There are a number of vital objections to Bergsten's proposal (Drysdale, Vines and House 1998:19). Foremost, it is entirely infeasible in that there is no collective action mechanism by which this proposal could be carried through within the loose APEC grouping. Under Article 24 of the WTO, a formal agreement and an agreed timetable would be required for WTO approval. APEC has eschewed any moves in this direction. 
APEC is not founded on an international agreement, nor does it possess any supra-national authority that would allow it to take collective action of the kind presumed in such calculations. There is no prospect that this will change, given the approach of Japan, East Asian and Western Pacific members to Asia Pacific economic cooperation.

Drysdale, Elek and Soesastro (1998) propose that a positive response to APEC's lead on trade liberalisation, in which the European Union commits itself to eliminating all border barriers to trade and investment by 2020 , would resolve the 'free rider' problem, about which Bergsten worries, and set the stage for effective cooperation among both groups to achieve free and open trade and investment between them as well as within each region.

This relates to the question of whether voluntary cooperation will be adequate to dealing with 'sensitive' sectors. Will it be possible to achieve deep liberalisation of agricultural trade in Northeast Asia, for example, without the pressure of hard negotiations and reciprocated exchange of concessions? The answer to this question may well be 'no'. But, consistently with the objectives and character of Asia Pacific economic cooperation, it is possible to plan ahead and deal with the liberalisation of some sensitive sectors in which there is also substantial extra-APEC interest within the WTO, consistently with its main principles. This should begin a few years down the track, after the digestion of Uruguay Round commitments and before the APEC industrial country freetrade deadline in 2010 . This strategy also presents a way of dealing with United States concern about European 'free riding', and offers the opportunity to lock Europe into liberalisation of border barriers comparable to that taking place within APEC.

Further, there is the question of whether the APEC formula can manage American lust for reciprocity, both from other APEC economies and from nonAPEC members. Over the next few years or so, this is not a major problem. In practice, the United States will itself largely 'free ride' within APEC as the major effect on liberalisation and internationally oriented reform continues to be in East Asia and the Western Pacific (Garnaut 1996:Ch. 1). This is reflected in the United States minimalist Individual Action Plan presented at Manila. The United States can best liberalise its remaining border measures in the context of broader WTO negotiations or an APEC Round. In this context there has been recent talk of reviving the trans-Atlantic initiative in a different form.

These reservations do not, in any way, suggest that APEC is simply a holding operation. Quite the reverse. They underline the importance of APEC in providing a vehicle for active trade and investment liberalisation when this is an urgent priority for the industrialising economies of East Asia and other economies in the Western Pacific, rather than their holding back until the next comprehensive WTO round of negotiations delivers an opportunity for policy progress. These 
are all elements of the utmost importance to China's trade policy and reform strategies.

\section{REFERENCES}

APEC, 1993. Economic Vision Statement, Seattle, November.

- 1994. Bogor Declaration of Common Resolve, Second APEC Economic Leaders Meeting, Bogor, November.

- 1995. Osaka Action Agenda: Implementation of the Bogor Declaration, Third APEC Economic Leaders Meeting, Osaka, November.

-, 1996. Manila Action Plan for APEC, Ministerial-level meeting, Manila, November.

- 1997. Leaders Declaration, Vancouver, 25 November.

APEC Eminent Persons Group (EM), 1994. Achieving the APEC Vision: Second Report of the Eminent Persons Group, Asia Pacific Economic Cooperation, Singapore.

Bergsten, C. Fred, 1997. 'Open Regionalism', The World Economy, 20(5):545-65.

Crawford, J.G. and Greg Seow (eds), 1981. Pacific Economic Cooperation: Suggestions for Action, Heinemann Asia, Petaling Jaya, for the Pacific Community Seminar.

Drysdale, Peter, 1988. International Economic Pluralism: Economic Policy in East Asia and the Pacific, Columbia University Press, New York, and Allen and Unwin, Sydney.

__, 1991. 'Open Regionalism: A Key to East Asia's Economic Future?', Pacific Economic Papers 197, Australia-Japan Research Centre, The Australian National University, Canberra.

- , 1997a. 'APEC and the WTO: Complementary or Competing?', Paper presented to the Institute of Southeast Asian Studies APEC Roundtable, Singapore, 6 August.

_- 1997b. 'The implications of China's Membership of the WTO for Industrial Transformation', Paper presented to a conference on Chinese Industrial Upgrade: International Transformation and International Cooperation, CASS, Beijing.

Drysdale, Peter and Andrew Elek, 1997. 'APEC: Community-building in East Asia and the Pacific', in Donald C. Hellman and Kenneth B. Pyle (eds), From APEC to Xanadu, The National Bureau of Asian Research, Seattle, and M.E. Sharpe, New York:37-49.

Drysdale, Peter, Andrew Elek and Hadi Soesastro, 1998. 'Open Regionalism: 
The Nature of Asia Pacific Integration', in P. Drysdale and D. Vines (eds), Europe, East Asia and APEC: a shared global agenda?, Cambridge University Press, Cambridge, UK:103-36.

Drysdale, Peter and David Vines (eds), 1998. Europe, East Asia and APEC: a shared global agenda?, Cambridge University Press, Cambridge, UK.

Drysdale, Peter and Ross Garnaut, 1989. 'A Pacific Free Trade Area?' in Jeff J. Schott (ed.), More Free Trade Areas?: Free Trade Areas and US Trade Policy, Institute for International Economics, Washington, DC:217-54.

Drysdale, Peter and Ross Garnaut, 1994. 'Principles of Pacific Economic Integration', in Ross Garnaut and Peter Drysdale (eds), Asia Pacific Regionalism: Readings in International Economic Relations, HarperEducational, Sydney:48-61.

Drysdale, Peter and Ligang Song, (eds), 2000. China's Entry to the WTO: Strategic Issues and Quantative Assessment, Routledge, London.

Drysdale, Peter, David Vines and Brett House, 1998. 'Europe and East Asia: A Shared Global Agenda?' in P. Drysdale and D. Vines (eds), Europe, East Asia and APEC: a shared global agenda?, Cambridge University Press, Cambridge, UK:3-30.

Elek, Andrew, 1995. 'APEC Beyond Bogor', Asian-Pacific Economic Literature, 9(1):1-39, May.

Flamm, Kenneth and Edward Lincoln, 1997. 'Time to Reinvent APEC', Policy Briefs, No. 26, Brookings Institution, Washington, DC.

Funabashi, Yoichi, 1995, Asia Pacific Fusion: Japan's Role in APEC, Institute of International Economics, Washington, DC.

Garnaut, Ross and Peter Drysdale (eds), 1994. Asia Pacific Regionalism: Readings in International Economic Relations, HarperEducational, Sydney.

Garnaut, Ross, 1996. Open Regionalism and Trade Liberalisation, Institute of South East Asian Studies Singapore, and Allen and Unwin, Sydney.

Hai Wen, 1996. 'Agricultural Policy Adjustment in the Process of Trade Liberalisation', paper presented at a conference on China and the WTO: Issues and Impacts on China and East Asian and Pacific Economies, Tokyo 8-9 May 1996.

Itoh, Motoshige, 1996, 'A Few Theoretical Remarks on China's Entry to the WTO' paper presented to a conference on China and WTO: Issues and Impacts on China and the East Asian and Pacific Economies, Tokyo, 8-9 May 1996.

Japan Pacific Cooperation Study Group, 1980. Report on the Pacific Basin Cooperation Concept, Prime Minister's Office, Tokyo.

Lu, Weiguo, 1994. 'China's GATT Re-entry and the Liberalisation of its Wool 
Textile Industry', paper presented to workshop on China and East Asian Trade Policy, The Australian National University, Canberra.

Miki, Takeo, 1968. 'Japan's Foreign Policy', speech delivered at the Australian National University, Canberra, 29 July.

Saxonhouse, Gary R., 1997. 'Regional Initiatives and US Trade Policy in Asia', Asian-Pacific Economic Literature, 11(2), November:1-4.

Song, Ligang, 1993. Sources of International Comparative Advantage: Further Evidence, PhD Dissertation, The Australian National University, Canberra.

Terada, Takashi, 1998. 'The Origins of Japan's APEC Policy: Foreign Minister Takeo Miki's Asia Pacific Policy and Current Implications, The Pacific Review, 11(3):337-65.

\section{NOTE}

This paper draws on work completed recently with Andrew Elek and Hadi Soesastro ('Open Regionalism: The Nature of Asia Pacific Integration', and David Vines and Brett House ('East Asia and Europe: A Shared Global Agenda?'). Many of the ideas and words are property shared with these colleagues. The argument in the paper is elaborated in Drysdale (1997a, 1997b). I am grateful to Ross Garnaut for his critical and helpful comments. I alone am responsible for the final shape of the argument. 